\title{
EFFECTS OF THE BULGARIAN BANKING SECTOR JOINING THE EUROPEAN BANKING UNION
}

\author{
Vania Ivanova ${ }^{1}$ and Ekaterina Sotirova ${ }^{2}$ \\ ${ }^{1}$ Prof. Dr., Department of Economics, University of National and World Economy, Bulgaria, \\ arbneda@abv.bg \\ ${ }^{2}$ Prof. Dr., Department of Economics, University of National and World Economy, Bulgaria, \\ sotirova_petkova@abv.bg
}

\begin{abstract}
The development of the Bulgarian banking system is a complex and dynamic process that is driven by the effect of both internal and external factors. The country's membership in the EU favours inflow of foreign capital into the system in the form of the purchases of most Bulgarian commercial banks. The domination of European capital forms a number of positives but also possibilities for distress by line of ownership.

As a Member State of the EU with derogation, Bulgaria does not participate in the European Monetary Union. However, apart from the choice of the euro as a nominal anchor of the Currency Board, it can also be observed that there is tighter integration with the European financial system and, over the last few years, government declarations expressing the desire to become a full member of the Eurozone. That leads to commitments that demonstrate the viewpoint that it is possible to achieve significant improvements of the main dimensions of the system's functionality while also increasing its credibility in the eyes of Bulgarian consumers of bank services and European investors.

In 2014, the Bulgarian bank system faced a serious challenge - the crisis surrounds Corporate Commercial Bank (CCB), one of its biggest commercial banks. The goal of this article is to examine the methods, effectiveness and costs of stabilizing the system. At the same time, the authors also examine the approaches that would have been applicable to the same situation had the country been a member of the European Banking Union and had CCB been under the Single Supervisory Mechanism. The task, based on the above-mentioned case, to evaluate the positives and potential negatives of Bulgaria joining the Banking Union and to support membership in the European Banking Union. That would contribute towards additional stabilization of the Bulgarian banking sector and more effective resolution of capital adequacy issues, liquidity, solvency and security.
\end{abstract}

Keywords: European Banking Union, bank supervision, banking system stability, financial integration 


\section{INTRODUCTION}

Facing the deepest crisis in a generation, the member state governments and EU institutions worked together to address the pressing sovereign debt challenges and implement measures to prevent similar downturns in the future. It is clear that without a sound banking sector and controlled sovereign debts, the chances of growth are slim. Without stability there is no confidence. And without confidence there is no growth. More than obvious was the need for urgent actions at the EU level and for targeted and adequate measures to restore the confidence in the financial institutions. At the same time, something deeply forgotten during the years came to light - the incomplete character of the economic and monetary union (EMU) and the need to reform the regulation and supervision of the banking sector.

The paper looks at the particularly important issue of the stability of the Bulgarian banking system and the prospects for its development. Since the introduction of the currency board arrangement in 1997, the banking sector has been largely stable. That is also evidenced by measurements such as the banks' capital adequacy, liquidity, and loan portfolio quality. In June 2014, however, one of the large Bulgarian banks experienced a crisis which adversely affected the whole economy. The issue of Bulgaria's membership in the European Banking Union (EBU) was brought to the fore.

The purpose of the paper is to analyse and infer the stability of the banking system in Bulgaria, draw the reasons leading to the crisis of Corporate Commercial Bank (CCB, also commonly referred to as KTB), and recommend one possible way of preventing similar situations. In parallel, the paper analyses the approaches which could have been applied to this same situation, had the country been a member of the European Banking Union and the CCB subject to supervision under the single supervisory mechanism. The task is, based on the particular case, to estimate the benefits and likely costs of joining the Banking Union and to support the idea of European Banking Union membership which would contribute to further stabilisation of the banking sector in Bulgaria as well as to more effective resolution of the capital adequacy, liquidity, solvency, and security issues. The illustrative data cover the period after 2011- the time when the country has gradually overcome the consequences of the crisis of 2009.

\section{CONDITION OF THE BANKING SYSTEM IN BULGARIA}

The development of the banking system in Bulgaria directly mirrors the condition of the real economy; however there are periods of time when the two processes do not run in parallel. On the whole, the sector has not been significantly affected by the crisis which started in 2007 in the USA and subsequently spread to Europe. Since 2009, the Bulgarian economy has fallen in recession; nonetheless the banking sector has continued to be profitable. A conclusion can be made that the banking system in Bulgaria is stable and the existence of temporary digressions from these conditions are linked to some internal factors, which however do not change the trend that has set in.

\subsection{Developments in the country's banking sector}

The specifics of the developments in the Bulgarian banking sector are conditioned by the following factors:

First, the system is relatively young insofar as its formation started in the early 1990s. Until the crisis of 1996/97, it was strongly influenced by the totalitarian methods of banking. The same was true with respect to the BNB policy. The crisis of mid-1990s is the most serious event in the recent history of banking in Bulgaria. It cleared the sector and created conditions for its stable operation.

Second - the introduction of the currency board on 1 July 1997. The currency board is a rigorously restrictive measure imposing serious constraints and prescriptions for the activities of commercial banks. In the absence of autonomous monetary policy, the measures applied by the BNB are mostly supervisory. Strengthening the supervisory role of the central bank exerts a positive influence on the banking sector developments.

Third - the openness of the economy. The banking environment in Bulgaria is dominated by foreign, mainly European capital. It holds more than $80 \%$ of total assets, $1 / 3$ of which is held by Greek banks. The majority of the large banks in Bulgaria are subsidiaries of major European banks. That has a stabilising effect on the system while implying a definite dependence on the policy of the parent companies. On the other hand, due to using the euro as a nominal anchor, the BNB follows the ECB's policy in its actions, thus also transferring a positive effect on the banking sector. 


\subsection{Measuring the stability of the banking sector}

The banking system of the country is stable and secure ${ }^{1}$. The system's stability can be measured using a set of indicators which give an insight into the ways the commercial banks in the country operate and of the level of their resilience to endogenous and exogenous shocks. The most important amongst these indicators are:

- capital adequacy and the buildup of capital buffers;

- $\quad$ liquidity situation in the banking system;

- loan portfolio quality and existence of nonperforming loans.

The capital adequacy requirements are laid down in Regulation No $575 / 2013^{2}$ of EU and in BNB Ordinance No $38^{3}$ on the Capital Adequacy of Banks. According to these, every bank is required to hold an amount of own funds which is adequate to its overall risk profile. Section III 'Calculation of capital adequacy', Article 6, paragraphs 6 and 7 set the capital adequacy level: the overall capital adequacy may not be less than 12 per cent and Tier 1 capital - no less than 6 per cent ${ }^{4}$. The data in Table 1 show a significant overrun of the capital adequacy indicators above the reference values across the banking system. The tangible change in 2014-2015 was due to the new methodology adopted by the BNB for their calculation.

Table 1: Indicators of Capital Adequacy of the Bulgarian Banking System for the Period 2011-2015

\begin{tabular}{|l|l|l|l|l|l|}
\hline Indicators & $\mathbf{2 0 1 1}$ & $\mathbf{2 0 1 2}$ & $\mathbf{2 0 1 3}$ & $\mathbf{2 0 1 4}$ & $\mathbf{2 0 1 5}$ \\
\hline Adequacy of Tier 1 capital, & 15,73 & 15,13 & 16,0 & 19,97 & 20,47 \\
\hline Total capital adequacy & 17,55 & 16,64 & 17,0 & 21,96 & 22,19 \\
\hline Capital Surplus, billion BGN (1) & & 2,6 & 2,8 & $6,9(2)$ & $7,0(2)$ \\
\hline
\end{tabular}

(1) Excess over the regulatory minimum capital

(2) Above the minimum requirement of $8 \%$

\section{Source:BNB}

Liquidity is another important factor which is central to achieving stability of the banking system. It is regulated by BNB Ordinance No $11^{5}$, according to which the banks must manage their liquidity in such a way so as to be able to carry out their daily tasks regularly and without delay both in a normal banking environment as well as in a situation of crisis ${ }^{6}$.

Table 2: Liquidity situation in the banking system 2012-2015

\begin{tabular}{|l|l|l|l|l|l|}
\hline Indicators & $\mathbf{2 0 1 1}$ & $\mathbf{2 0 1 2}$ & $\mathbf{2 0 1 3}$ & $\mathbf{2 0 1 4}$ & $\mathbf{2 0 1 5}$ \\
\hline Liquid assets ratio (1), in\% & 25,5 & 26,0 & 27,0 & 30,1 & 36,7 \\
\hline Annual change in liquid assets, billion BGN, & 1,45 & 1,581 & 1,616 & 2,181 & 5,468 \\
\hline Amount of Liquid Assets of the Banking System (1), billion BGN & 16,8 & 18,4 & 20,0 & 22,2 & 27,7 \\
\hline -percent of the total assets of the banking system & 17,4 & 22,3 & 23,4 & 26,1 & 31,6 \\
\hline
\end{tabular}

(1) By the end of December for the relevant year.

Source: BNB

\footnotetext{
${ }^{1}$ P.Biolcheva, Current situation of the commercial banks in Bulgaria, 25 Years Department of National and Regional Security, Sofia, Publishing House at UNWE, 2016,

${ }^{2}$ Regulation (EU) No 575/2013 of the European Parliament and of the Council of 26 June 2013 on prudential requirements for credit institutions and investment firms and amending Regulation (EU) No 648/2012, published in Official Journal of the European Union of 27.06.2013.

${ }^{3}$ BNB, Ordinance No 38 on the Capital Adequacy of Banks

${ }^{4}$ BNB, Ordinance No 38, page 6.

${ }^{5}$ BNB, Ordinance No 11 on Bank Liquidity Management and Supervision.

${ }^{6}$ There again, Article 1, paragraph 2.
} 
The review of the performance of the key indicators for banking system liquidity (Table 2 ) indicates that in general the system stood above the recommended $20 \%$ threshold for the liquid assets coefficient calculated as a ratio between liquid assets and the amount of liabilities. Liquid assets are dominated by cash, funds on current accounts with banks, and interbank deposits of up to 7 days. Probably under the impact of the crisis with Corporate Commercial Bank and First Investment Bank in 2015, liquid assets increased by more than 3 billion levs reaching 5,4 billion levs. To a certain degree, it could be considered that the system has a high level of liquidity, which on the one hand is a good signal with regard to stability, although likely to have a negative effect on profitability.

An important measurement of the banking system stability is the state of its assets, in particular the existence of nonperforming loans and significant arrears on these loans. The reasons for such elements to appear in the banks' assets stem from the situation of the real economy insofar as the low incomes of borrowers, the lack of employment and the issues encountered by households lead to nonperformance of obligations. The BNB Annual Reports ${ }^{7}$ since 2011 reveal that the credit risk is leading for the banking system. That is also confirmed by the data in Table 3.

Table 3: Gross credit exposures past due over 90 days,

\begin{tabular}{|c|c|c|c|c|}
\hline Indicators & $\mathbf{2 0 1 1}$ & $\mathbf{2 0 1 2}$ & $\mathbf{2 0 1 3}$ & $\mathbf{2 0 1 4}$ \\
\hline Annual Growth & 13,7 & 5,7 & 14,6 & $-5,1$ \\
\hline Share in Gross Loans & 14,97 & 16,6 & 16,9 & 16,75 \\
\hline Coefficient of Coverage & 46,1 & 48,0 & 52,5 & 59,1 \\
\hline
\end{tabular}

\section{Source:BNB}

The data used in the Table are until 2014, as since 2015 the BNB has changed the methodology of reporting nonperforming loans. At the end of the year (2015), the amount of nonperforming exposures was 11,2 billion levs, of which 11,158 in loans and advances. The total amount of gross loans and advances is 74,5 billion levs - the share of nonperforming loans being $15,5 \%$. Past-due exposures of above one year are 6,9 billion levs, while the net amount of gross nonperforming loans is 5,7 billion levs, fully covered by the capital in the banking system $-11,5$ billion levs (own funds). The structure of nonperforming exposures as at the end of 2015 is also of interest: non-financial enterprises $-71,0 \%$, households $-27,9 \%$, other financial enterprises $1,1 \%$, and a negligible share of credit institutions $-0,0 \%$.

\subsection{The crisis of Corporate Commercial Bank}

Since the introduction of the currency board in the country, the banking sector has practically encountered a serious challenge in its development. That is the crisis of one of the large Bulgarian banks - Corporate Commercial Bank - of June 2014. CCB was set up in 1994 as a subsidiary to the major Bulgarian bank Bulbank, presently owned by the Italian UniCredit bank. Later on, owner of the bank became the Bulgarian the bank's CEO with shares in the bank's capital also held by the Sultanate of Oman, the Italian insurance holding company Generali, and the Russian VTB. As of early 2014, the bank held above 7 billion levs in assets (circa 3,6 billion euro) and ranked third in the country in terms of profitability and forth in terms of size. It also ranked first in terms of rate of increase of deposits. The bank held over $8 \%$ of the funds of the country's population - citizens and businesses. A procedure was started to acquire the French Credit Agricole Bulgaria.

The bank, before the liquidity crisis and its practical closure in the middle of 2014 , was characterised by the following:

- The bank followed an aggressive interest rate policy It offered high interest rates on deposits reaching up to $7 \%$, which was a serious departure from the country's average level in the period 2000-2014. This way, it attracted substantial savings from both large depositors and small savers. The rate of increase of deposits was impressive.

- The bank had 150 large debtors holding $97 \%$ of all loans. To loans granted to 59 of these firms, which were actually 'dummy' entities, i.e. with no employees or workers, amounted to 2,3 billion levs (1,65 billion euro). Another 1,6 billion levs ( 0,8 billion euro) of loans were extended to firms, each of them

\footnotetext{
${ }^{7}$ BNB, Annual reports for the relevant years
} 
having no more than 10 employees.

- The bank's management, its CEO in particular, were closely connected with the political life in the country. It would be somewhat true to say that there were serious attempts at influence, with the bank also enjoying political protection. Also, CCB was closely connected with the media market which allowed it to enjoy comfort in the press and to follow actions that, in the general sense of the word, were unacceptable from the perspective of the overall public interest.

- As a consequence of the above, nearly half of the government funds - central and local government authorities - were deposited on accounts with the bank. CCB, in turn, held shares in BTK, Bulgartabak, Technomarket, Dunarit, Petrol and other large firms, i.e. practically merging banking with industry capital. While not a bad approach in itself, it nevertheless hid the risk of problems that could arise if any one of the parties were to fail. Bulgartabak was the firm whose problems put the beginning of CCB's discrediting.

- In the middle of June 2014, a massive run on the bank triggered a liquidity crisis and caused the bank to stop its activities. The BNB placed it under special supervision. On 06.11.2014, the central bank revoked CCB's license. It came out that the bank had indirectly extended loans to itself. Out of the total amount of 5,4 billion levs in loans (2,7 billion euro), the loans to the CEO-related firms came to some 3,5 billion levs (1,75 billion euro), or $65 \%$ of all loans and around $49 \%$ of the bank's total assets. That was in serious conflict with the regulatory rules governing the banking sector.

The implications for the economy as a whole, the banking sector, and the macroeconomic policy can be sought along the following lines:

Some sectors of the economy incurred severe losses. One of these was the military industrial complex. The overall loss for the economy in this sector amounts to 1 billion levs, of which 300 million levs in unpaid salaries, 500 million levs in unpaid bills to providers, and 200 million levs in unpaid taxes to the budget. Approximately 100 thousand workers in the sector were affected. A large portion of the monetary assets of the energy sector was held with CCB. Bulgargaz had $98,5 \%$ of its funds placed with the bank. The Bulgarian energy holding held over $25 \%$ of its funds with the same bank. CCB also serviced the Kozloduy Nuclear Power Plant and the District Heating Company of Sofia, Toplofikacia Sofia, to name a few. The municipalities deposited 110 million levs; the universities in the country - 22 million levs, and hospitals - 18 million levs.

The crisis which mainly affected the CCB and also exerted pressure on the deposits of First Investment Bank led to deteriorated expectations in the economy. That had an impact on the plans of investors - internal and external alike. Besides, budget funds of some 1,5 billion levs (750 million euro) were allocated to the Deposit Insurance Fund to cover the legally required guaranteed amount of 100,000 euro payable to private or business depositors. The state also supported the municipalities by compensating around half of their lost funds.

One of the reasons for the situation around Corporate Commercial Bank was the weak supervision exercised by the Central Bank. That led to the replacement of the BNB Deputy Governor in charge of Banking Supervision. The losses, on a broader scale, can furthermore be measured with the impaired trust in the central bank, particularly its supervisory policy. ${ }^{8}$

\section{EFFECTS OF A EUROPEAN BANKING UINION MEMBERSHIP}

By joining and being a full member of the EBU, Bulgaria could actively benefit from both the general membership advantages, as well as from the specific advantages entailed for the particular banking system.

\subsection{General benefits}

The lessons from the crisis of 2008 have clearly shown that bank failures can pose a systemic risk. The setting up of the EBU ${ }^{9}$ and Bulgaria's joining is an effort to find effective solutions to minimise this risk. Under an arrangement of strong commitment of the banking systems and a monetary union such additional guarantee is of huge importance.

Also, a union of this kind contributes to reducing the differences in the funding conditions across member countries (currently only within the euro area, with a possibility, however, for the other EU countries to participate). That obviously leads to better allocation and efficiency of the production factors.

\footnotetext{
${ }^{8}$ Investigations and debates on the "Corporate Commercial Bank" case continue on an ongoing basis (2017).

${ }^{9}$ Created, according on Art.114 and Art.127, par. 6 of the TFEU, or the idea for it is developed and specified in an official document entitled "Towards a genuine Economic and Monetary Union" / "The report of the four presidents" /.
} 
Within the EBU, the EU conducts stress tests (asset quality review) which are intended to show the actual state of the banks under direct supervision and diagnose the likely need for recapitalisation, recovery or closing down of bank institutions. In parallel with the supervision, the Single Resolution Mechanism imposes identical procedures and terms of restructuring of problem banks within the union.

Essentially, with the introduction of the bail-in mechanism at EU level, the possibility of transferring the losses of problem banks to the budget, and hence to taxpayers, is prevented. That breaks the 'vicious link' between exerting pressure on the public indebtedness of member states, on the one hand, and the deteriorated state of the debt weighing heavily on the banks' balance sheets.

Only savings of up to 100,000 euro and holders of secured debt instruments remain guaranteed. All costs are borne by the shareholders and depositors. In the event of shortfall, recourse can be made to the common resolution fund ${ }^{10}$, which is set up by the banks themselves, but up to a maximum of $5 \%$ of assets.

This solidarity mutual fund of the banks within the EBU is entrusted with the responsible task to break the 'vicious circle' between the bank failures and the sovereign debt crisis. Its gradual buildup since 2016 over an 8 years' period amounting to 55 billion euro (which is only $1 \%$ of the deposits of the banks from the EBU) aims to place the emphasis on the responsible behaviour of the banks themselves, rather than turn the fund into a 'lifebelt"'.

It should, however, be stressed that a fund of this kind, albeit needed, would be extremely insufficient in a situation of a banking crisis similar to the one of 2008. Even if the fund itself could resort to loans from the financial markets, so far there is neither consent nor clarity as to whether these loans would be commonly guaranteed by the member states. Therefore the danger of resorting once again to bailout from the budget and a direct government support is not at all eliminated.

A possible solution in this direction is the increase of resources accumulated in the resolution fund, higher own funds requirements for banks, even further tightening of the supervision especially over the smaller banks which are outside the direct control of the ECB, and a more active participation of the European Stabilisation Mechanism. That gives additional security, increases the confidence in the EBU, and provides a higher guarantee.

The Single Resolution Mechanism (SRM) aims to unify the actions for recovering problem banks and limit the risk of 'contaminating' the banking and financial system. The responsibility for diagnosing problem banks belongs to the ECB while the Resolution Committee is in charge of the control over the process of resolution (or closure) at the national level.

This supranational control, equipped with the appropriate tools to minimise the costs of resolution for taxpayers, which would basically be borne by the shareholders and depositors (above the guaranteed amount), could be the powerful factor to reactivate the market that has been loose for years.

Another important task and advantage of the SRM is reducing the resolution time, which in turn is closely linked to both the costs of the process and to limiting the 'contagion' effects on the banking sector in the country.

Taking over the implementation and control of the process of resolving a bank (especially a systemically important one) from the hands of local (national) interests ensures that no political or lobbyist pressure is exerted and the efficiency of the process thus compromised.

\subsection{Specific benefits for Bulgaria}

The banking crisis triggered by the CCB case revealed weaknesses in the banking supervision conducted by the $\mathrm{BNB}$, which affected the overall trust in and attitude to the institution. A radical political decision is needed to overcome this distrust. The first step was made with the political agreement reached already in mid-July 2014 for immediate actions towards Bulgaria joining the EBU.

Until accession to the euro area, Bulgaria can participate in the European Supervisory Mechanism (ESM) ${ }^{11}$ through the so-called Close Cooperation Mechanism, which the single supervision offers as an advantage, however with no voting rights in the decision making process of the Board of Supervisors.

The ESM, already in place, entrusted to the ECB the function of direct supervision of the most significant

\footnotetext{
10 The Fund is envisaged to be fully completed only in 2023. It can cover $5 \%$ of a bank's liabilities, but only after the shareholders and unsecured depositors have covered the first losses of $8 \%$ of the liabilities.

${ }^{11}$ A Declaration of the European Union of 29.06.2012 put the beginning of a new political stage in the development of the Eurointegration - a transition from coordination of the national banking supervision to a direct single European supervision.
} 
circa 130 out of a total of over 6000 euro area banking institutions. A possibility is envisaged, where necessary and on discretion, for the ECB to also take the supervision over smaller banks which are subject to the national supervisory institutions, where that is considered appropriate.

The ESM allows for a coherent approach to be applied to the supervision of risk management, including a cross-border one. This approach facilitates the identification and prevention of the risk in the banking sector. Its adoption imposes an appropriate and unified regulation throughout the EU (and not only within the euro area, thereby avoiding the formation of areas differing in speed and rules).

That is especially relevant for Bulgaria, which, although outside the euro area, operates a currency board arrangement and has a significant number of banks foreign owned by euro area countries.

The major benefits of Bulgaria's accession to the European Banking Union is eliminating the local political connectedness with the management of the Bulgarian banks and limiting the nonrational financial interests exerting negative influence over the activities of some of the banks and their supervision. The BNB integration into the single supervisory mechanism will ensure to a large extent a greater operational independence of the banking supervision activities based on strict compliance and adherence to the common European rules and supervisory methodologies and under the control, governance and procedures adopted by the Board of Supervisors of the European Central Bank. Apart from the direct supervision of the three largest banks, the ECB takes over the oversight of all banks bailed out by the state.

None of the banks operating in Bulgaria directly meet the significance criteria. However, it should not be forgotten that a bank's size is not the only factor of systemic and banking risk. More often, the problem banks are actually medium and sometimes even smaller, rather than large-sized ones. That was also the case with CCB. Crucial for the problems of this bank (as was made clear in part 1 of the paper) were the political and lobbyist interests, as well as the indulgence received from the national supervision. The insider loans extended to the majority owner reach $33.36 \%$ (while the law permits 10\%). Had the country participated in the EBU and had the Single Supervisory Mechanism been accordingly applied, it would have been more difficult to break the rules.

The procedure itself of placing the bank under special supervision all through to the decision of closing down the bank and paying off the guaranteed deposits took more than five months. The European Commission of the EU even sent a warning letter to the BNB to speed up the process of paying off depositors from the Bulgarian Deposit Insurance Fund. The Fund itself had 1,1 billion euro while the guaranteed deposits with CCB and Victoria Bank amounted to 1,9 billion euro. The bail-out mechanism implied covering the difference from the budget by means of a sovereign debt (based on a political agreement).

The unclear and cumbersome resolution procedures, the emptying of the Deposit Insurance Fund and the taking of further risk of increasing the cost for the budget and taxpayers in the event of a new banking crisis, and above all undermining the confidence in the banking sector, was the price, which the country had to pay for the CCB case.

Even joining the EBU would not eliminate such risk completely, especially for the smaller banks remaining under national supervision. It would however enhance the control and quality of that supervision. Concentrating more control and more information about the condition of the banking sector into the hands of the ECB enables a much earlier and timely response in the event of risk. Clearly, this also benefits the resilience of the banking system and guarantees microprudential security. Joining EBS is also a step towards tackling the macroeconomic imbalances of the country, with recommendations being made mostly in the financial sphere. This way, both the monetary as well as the fiscal stability increases. In this regard, the participation in the EBU is an additional assurance not just for financial stability, but also for economic and political stability.

Therefore, the 'cooled off enthusiasm' for joining the EBU, abandoning the debate for membership and underestimating the risk of similar crises in the future are unjustified.

A strong point of the ESM, which not only helps identify the actual situation of the key systemically important banks, but also to assess their preparedness to react in a situation of liquidity crisis, are the stress tests conducted under the control of the ECB. For Bulgaria, which after what happened with the CCB also carried out such an assessment in the summer of 2016 (using a similar while not completely identical methodology with that of the ECB), that was of great benefit.

It became evident that the majority of the banks are stable, without any serious problems and could relatively smoothly withstand even a negative scenario. Most of these banks, however, are subsidiaries to European banks from EBU member states. The reason for this provisional division is the better risk management by foreign banks and above all the higher standards coming from the parent banks, that is, the imported 


\section{banking practices.}

The banks that showed a need for recapitalisation or were close to the critical threshold were Bulgarianowned banks. That is an indirect proof of the benefits and the disciplinary effect of the EBU membership.

The individual results from the asset review across banks indeed demonstrate that all regulatory requirements are met even after the corrections. The amount of corrections by banks speaks of a somewhat different behaviour of some local banks which were imposed corrections and had to increase their capital accordingly.

It is of concern that the vast majority of the corrections were in two banks with Bulgarian owners, of which around 420 million levs are the corrections of FIB only, which is the third largest bank in the country. Its capital shrinks from $11.3 \%$ to $5 \%$ - close to the regulatory minimum and remains one of the two banks with a capital adequacy below $11 \%$ after the asset review (along with Investbank).

These two banks are the only ones indicating negative results under the hypothetical adverse stress test scenario, with the FIB's capital falling down to $-6.9 \%$, which explains the efforts of the bank to increase its capital adequacy in the following months. The BNB's report on the stress test outcomes does not reveal any specific data concerning the risk exposures with connected persons - which was exactly the problem causing the CCB's collapse.

Another significant advantage of the single supervision is the higher transparency and accountability. There is an enhanced public control over the activities on two levels - national and European. At the European level the control is exercised through the relevant committee in the European Parliament and the Council of Financial Ministers of the euro area countries. The functioning and efficiency of the single supervision is subject to audits by the European Court of Auditors, while the ECB activities can be investigated by the European Parliament.

For a country like Bulgaria, where the dominating part of the banking system is held by foreign European banks, the participation in the EBU has yet another advantage. It follows from the assumption that the crossborder activity of banks will concentrate more within the banking union due to the greater homogeneity of the rules governing their activities. The enhanced surveillance which runs in parallel with the completion of the union would undoubtedly discipline the banks and increase the confidence among investors and savers.

\section{CONCLUSION}

The benefits of our membership in the European Supervisory Mechanism and subsequently in the European Banking Union by far outweigh the costs. This is a kind of a general assurance (by accessing the resolution fund, counteracting the fiscal pressure, and using a single guarantee scheme). That, of course, raises some further issues related to a genuine reform of the banking structure in $\mathrm{EU}$ and the compatibility of risks for the different banks feeding up with their contributions the resolution fund and the fund guaranteeing deposits of up to 100,000 euro.

The banking system experiences some credibility deficit and requires changes. Investors are still equally insecure in the reliability of the bank balance sheets, the strictness of the national supervision, as well as the state's ability to ensure the necessary funds to guarantee deposits. In this sense, the added security assurance and reinsurance at the supranational level, which the EBU provides, is to some extent a response to the need of change in the banking sector. That would restore the impaired confidence, would ensure quality of assets and enhance the stability of the banking system in the country. The adoption of the bail-in mechanism leads to breaking the chain of 'banking crisis-debt crisis-deteriorated fiscal position of the country'.

The EBU should indeed be regarded as a precondition, as a necessary, yet insufficient, condition for the proper functioning of the financial system in Bulgaria. This union could hardly resolve all problems, or in any case, not so quickly and at once.

The shaping of a public consensus for adoption and speeded-up implementation of this plan would ensure the needed clarity and logical sequence by assuring the stability of the banking and financial sectors, the payment of guaranteed deposits, and our integration into the single supervisory mechanism. This way, the process of European integration of the banking sector would run smoothly laying the grounds for the subsequent adoption of the single currency.

What's more, the developments in the EU in 2016 and the real threat of a 'two-speed Europe' also lead to the conclusion that Bulgaria must take steps towards the EBU as soon as possible or else risk to stay 'behind board' of the major integration processes. 


\section{REFERENCE LIST}

Biolcheva,P., Aktualno sastoyanie na targovskite banki v Balgaria, Sb. 25 godini katedra "Natzionalna I regionalna sigurnost", Izdatelski complex na UNSS, 2016.

BNB, Annual Reports.

BNB, Naredba 11 za upravlenieto I nadzora varhu likvidnostta na bankite.

BNB, Naredba 38 za kapitalovata adekvatnost na bankite.

Reglament (ES) 575 na Evropeiskiya parlament I na saveta ot 26.06.2013 otnosno prudentzialnite izskvaniya za kreditnite institutzii I investitzionnite posrednitzi

Ferran, E., et Babis, V., The European Single Supervisory Mechanism, University of

Cambridge Faculty of Law Legal Studies Research Paper Series, 2013.

Gortsos, C. VI., «The "Single Supervisory Mechanism": a major building-block

towards a European Banking Union (the full Europeanisation of the "bank safety

net")», 2 conference annuelle sur la recherche de l'IADI, 2013.

Huertas, T., et Nieto, M. J., «Banking union and bank resolution: How should the

two meet?», VOX, 2012.

Kern, A., Bank resolution and recovery in the EU: enhancing banking union?,

ERA (Acadŭmie de droit europŭen), 2013.

Lannoo, K., Banking Union in three steps, Centre d'etudes de la politique europeenne,

Commentaire du CEPS, 2012.

Lane, P (2015), “Macro-financial stability under EMU”, CEPR Discussion Paper 10776.

Martin, P and T Philippon (2014), "Inspecting the mechanism: Leverage and the great recession in the Eurozone", Working Paper NYU.

Véron, N and G Wolf (2015), "Capital markets union: a vision for the long term", Bruegel Policy Contribution, April 